\title{
Solidaritas Pangan Jogja sebagai Aktor Alternatif Penyedia Kesejahteraan di Masa Krisis Pandemi COVID-19
}

\author{
Saqib Fardan Ahmada ${ }^{1}$, Fernandito Dikky Marsetyo ${ }^{2}$, Rizqy Anita Putri ${ }^{3}$
}

\begin{abstract}
Abstrak
Tulisan ini membahas munculnya aktor alternatif berbasis jaringan dukungan sosial di tengah keterbatasan negara dalam menyediakan jaring pengaman saat krisis berlangsung. Dengan menggunakan kerangka teori informal security regime dan jaringan dukungan sosial, tulisan ini bertujuan untuk menjelaskan bagaimana Solidaritas Pangan Jogja (SPJ) bergerak dalam mendistribusikan makanan untuk pekerja informal dan kelompok rentan di Yogyakarta saat krisis akibat pandemi COVID-19. Penelitian dilakukan dengan metode kualitatif melalui pendekatan studi kasus dengan analisis deskriptif. Penelitian menunjukkan bahwa SPJ merupakan aktor alternatif yang berbasis jaringan dukungan sosial dan berperan sebagai jaring pengaman dengan memenuhi kebutuhan dasar berupa makanan. Tulisan ini berargumen bahwa meskipun gerakan yang dilakukan dapat memberikan bantuan dengan cepat, gerakan semacam ini juga memiliki kerapuhan dalam hal sumber daya manusia dan sumber daya finansial. Kerapuhan tersebut membuat praktik jaringan dukungan sosial seperti SPJ merupakan model yang tidak permanen dan mudah berubah.
\end{abstract}

Kata Kunci: aktor alternatif; krisis; jaringan dukungan sosial; solidaritas pangan jogja

\begin{abstract}
This article discusses the emergence of alternative actor based on social support networks amid state limitations in providing safety nets during the crisis. Using the theoretical framework of informal security regime and social support networks, this article aims to explain how Solidaritas Pangan Jogja (SPJ) moves in distributing food to informal workers and vulnerable groups in Yogyakarta during the crisis due to COVID-19 pandemic. The research was conducted with qualitative methods through case study with descriptive analysis. It shows that SPJ is an alternative actor based on social support network and acts as a safety net by fulfilling food as a basic need. This article argues although this movement has capacity to provide a responsive social assistance, it is also has a fragility in terms of human and financial resources. Its fragility tends to cause social support networks such as SPJ is not permanent and unchanging form.
\end{abstract}

Keywords: alternative actor; crisis; social support network; solidaritas pangan jogja

\section{Pendahuluan}

Persebaran Coronavirus Desease 2019 (COVID-19) menjadi isu aktual global yang semakin berkembang sejak akhir tahun 2019. WHO mendeklarasikan COVID-19 sebagai pandemi global setelah virus tersebut menyebar ke lebih dari 100 negara dalam kurun waktu tiga bulan (WHO, 2020). Berdasarkan data WHO pada awal bulan September 2020, jumlah konfirmasi kasus positif di seluruh dunia sebanyak 27.738.179 orang dengan angka kematian mencapai 899.916 jiwa. Di Indonesia, total kasus konfirmasi positif pada awal September 2020 mencapai lebih dari 200 ribu orang, dengan jumlah kematian lebih dari 8.300 jiwa (WHO, 2020).

Guna mengurangi persebaran COVID-19, WHO menghimbau negara-negara di dunia untuk menerapkan kebijakan physical distancing (WHO, 2020). Dalam konteks Indonesia, hal ini diwujudkan melalui penetapan status keadaan darurat bencana COVID-19 dan Pembatasan Sosial Berskala Besar (PSBB) di beberapa wilayah. Secara spesifik, hal ini dapat dilihat dari adanya kebijakan penutupan sekolah dan tempat kerja, pembatasan kegiatan keagamaan, pembatasan kegiatan di tempat/fasilitas umum, pembatasan kegiatan sosial budaya, dan

\footnotetext{
${ }^{1}$ Departemen Pembangunan Sosial dan Kesejahteraan, Universitas Gadjah Mada (email korespondensi: saqib.f@mail.ugm.ac.id)

${ }^{2}$ Departemen Pembangunan Sosial dan Kesejahteraan, Universitas Gadjah Mada (email: fernandito.d@mail.ugm.ac.id)

${ }^{3}$ Departemen Pembangunan Sosial dan Kesejahteraan, Universitas Gadjah Mada (email: rizqy.anita.putri@mail.ugm.ac.id)
} 
pembatasan moda transportasi. Hal ini telah memunculkan konsekuensi berupa turunnya mobilitas masyarakat (LIPI, 2020; BPS, 2020). Dampaknya, aktivitas kerja dan produksi ekonomi menjadi terhambat bahkan berhenti.

Lesunya aktivitas ekonomi membuat pelaku usaha harus berhitung cermat untuk keberlangsungan operasionalnya. Demi efisiensi, beberapa perusahaan menerapkan kebijakan berupa pemotongan gaji, merumahkan karyawan, hingga melakukan pemutusan hubungan kerja (Bagus et al., 2020; Juaningsih, 2020). Bedasarkan data Kementerian Ketenagakerjaan RI, tercatat per-20 April 2020, pekerja yang terdampak COVID-19 jumlahnya mencapai 2.084.593 ribu pekerja yang berasal dari 116.370 ribu perusahaan. Lebih jelasnya, terdapat 1.304.777 ribu pekerja dari 43.690 ribu perusahaan yang dirumahkan. Sedangkan sebanyak 241.431 ribu pekerja dari 41.236 ribu perusahaan mengalami PHK (Kementerian Ketenagakerjaan, 2020). Tak hanya ekonomi sektor formal yang terpukul, ekonomi sektor informal turut mengalami hal serupa. Hasil riset Lembaga Ilmu Pengetahuan Indonesia (2020) dan Asosiasi Business DevelopmentServices Indonesia (2020) menunjukkan hampir seluruh usaha mikro, kecil, dan menengah (UMKM) melaporkan adanya penurunan penjualan yang berakibat pada turunnya laba usaha yang signifikan.

Paparan tersebut menggambarkan bahwa COVID-19 telah menghadapkan masyarakat pada ancaman risiko yang nyata. Adanya lonjakan pengangguran, berkurangnya pendapatan, dan ketidakpastian pasar kerja menjadi hal yang sulit terhindarkan. Beberapa studi (Sumner et al., 2020; Suryahadi et al., 2020) menjelaskan bahwa pandemi berpotensi akan meningkatkan jumlah masyarakat miskin baru. Diprediksi akan ada 8,5 juta orang yang berpotensi menjadi miskin pada skenario terberat jika pertumbuhan ekonomi tahunan hanya bergerak pada kisaran $1.0 \%$ (Suryahadi et al., 2020). Studi yang lain (Alkire et al., 2020; Rahmanda et al., 2020) menunjukkan bahwa terdapat korelasi positif yang kuat antara jumlah orang berisiko terinfeksi COVID-19 dengan jumlah orang yang hidup dalam kondisi miskin multidimensi. Artinya, di masa pandemi saat ini, masyarakat miskin tengah dihadapkan pada dua ancaman sekaligus, yaitu ancaman kesehatan dan ancaman ekonomi.

Berangkat dari kondisi tersebut, pemerintah merespon dengan memberikan beberapa skema
Jaring Pengaman Sosial (JPS). Berbagai JPS tersebut diwujudkan dalam berbagai program, diantaranya: 1) Penambahan penerima dan besaran manfaat Program Keluarga Harapan (PKH) dan Kartu Sembako 2) Kartu Pra Kerja, 3) Subsidi biaya listrik, 4) Operasi pasar dan logistik, dan 5) Pembayaran kredit bagi kelompok informal (Knowledge Sector Initiative, 2020). Meski demikian, program-program yang telah diberikan dinilai belum menjawab persoalan di masyarakat. Hasil survei Indikator Politik Indonesia (2020) dan Saiful Mujani Research \& Consulting (2020), menunjukkan bahwa bantuan sosial yang diberikan belum tepat sasaran. Di samping persoalan tersebut, terdapat polemik lain pasca bantuan sosial terdistribusikan, diantaranya terdapat perbedaan kebijakan yang didasarkan pada Surat Edaran Nomor 8 Tahun 2020 dari Menteri Desa PDTT dan Intruksi Menteri Dalam Negeri Nomor 3 Tahun 2020 (Mufida, 2020). Pada sumber yang sama, dijabarkan pula sederet permasalahan distribusi bantuan sosial lainnya, seperti penggunaan data yang tidak valid, permasalahan aksesibilitas untuk memperoleh bantuan, hingga pungutan liar yang dilakukan pejabat setempat. Persoalan lain adalah adanya polemik Kartu Pra Kerja seperti dugaan konflik kepentingan, bentuk insentif, efektivitas program, penerima kartu, sampai pada persoalan efisiensi anggaran (Indonesia Corruption Watch, 2020). Kartu Pra-Kerja juga dianggap kurang tepat apabila dikeluarkan sebagai jaring pengaman sosial di tengah pandemi COVID-19 (Consuello, 2020).

Ketika pemerintah menunjukkan keterbatasan dalam menyediakan jaring pengaman sosial, di sisi lain muncul berbagai aksi solidaritas dari masyarakat. Berakar pada inisiatif untuk saling membantu di tengah pandemi, aksi solidaritas ini menjadi upaya resiliensi masyarakat dalam merespon krisisyang terjadi. Gerakan ini dapat dilihat dari munculnya Solidaritas Pangan Jogja (SPJ). Keberadaan SPJ sendiri pada awalnya merupakan bentuk inisiatif untuk membantu masyarakat yang mengalami kesulitan ekonomi akibat adanya pandemi. SPJ bergerak membantu masyarakat dengan cara membagikan makanan kepada kelompok yang dianggap rentan. Upaya yang dilakukan oleh SPJ menjadi potret dari hadirnya peran masyarakat sebagai aktor alternatif dalam penyediaan kesejahteraan. Tulisan ini akan menjelaskan bagaimana SPJ bergerak sebagai aktor alternatif 
dalam penyediaan kesejahteraan untuk pekerja informal dan kelompok rentan di tengah krisis pandemi COVID-19.

\section{Kerangka Teori}

Informal Security Regime

Konsep rezim kesejahteraan menurut Sumarto (2017) berkembang setelah publikasi buku monumental karya Esping Andersen pada tahun 1990. Rezim kesejahteraan merupakan rangkaian pengaturan kelembagaan, kebijakan, dan tradisi yang memengaruhi kesejahteraan dan struktur sosial di masyarakat (Gough, 2004:26). Pada tahap awal, Esping Andersen (1990) melalui bukunya The Three World of Welfare Capitalism menjelaskan bahwa rezim kesejahteran hanya mencakup peran negara kesejahteraan saja. Dalam perjalanannya, kajian rezim kesejahteraan semakin dikembangkan dengan mulai mempertimbangkan konteks negara-negara berkembang.

Gough (2004) dalam tulisannya menjelaskan bahwa terdapat perbedaan khusus antara rezim kesejahteraan di negara kesejahteraan dan negara berkembang. Perbedaan yang utama dapat dilihat dalam hal penyediaan kesejahteraan (welfare provision). Satu hal pokok yang membedakan menurut Gough adalah tentang bagaimana welfare mix dimodifikasi dalam konteks negara berkembang. Seperti halnya dikatakan Wood (2004:56)dan Gough (2004:30) bahwa dengan menambahkan segitiga Esping Andersen dari negara-pasar-rumah tangga dengan memasukkan aktor komunitas. Menurutnya, dalam konteks negara berkembang, komunitas memiliki peran tersendiri dalam upaya penyediaan kesejahteraan.

Adanya peran komunitas kemudian memunculkan istilah yang disebut dengan informal security regime (Wood, 2004). Hal tersebut dapat dilihat dalam kondisi ketika masyarakat mengandalkan peran hubungan keluarga dan masyarakat untuk dapat mengakses kesejahteraan. Seperti dijelaskan:

"An informal security regime reflects a set of conditions where people cannot reasonably expect to meet their security needs via accessing services from the state or via participation in open labour markets. Thus, they have to rely more heavily upon community and family relationships of various kinds."(Wood, 2004:50).

Secara khusus, kondisi ini memusatkan perhatian pada pentingnya sumber daya sosial dan kultural di tingkat komunitas dan keluarga untuk mengejar penghidupan yang aman, selain peran negara dan pasar (Wood, 2004). Dalam konteks Indonesia, praktik demikian bukan hal baru. Secara historis, model kesejahteraan berbasis masyarakat ini sudah ada dalam tradisi masyarakat Jawa. Berlandaskan semangat gotong royong, masyarakat Jawa sudah mengenalkan sistem penyediaan kesejahteraan informal seperti arisan, layatan,

Gambar 1

Perbedaan Aktor Kesejahteraan di Negara Kesejahteraan dan Negara Berkembang
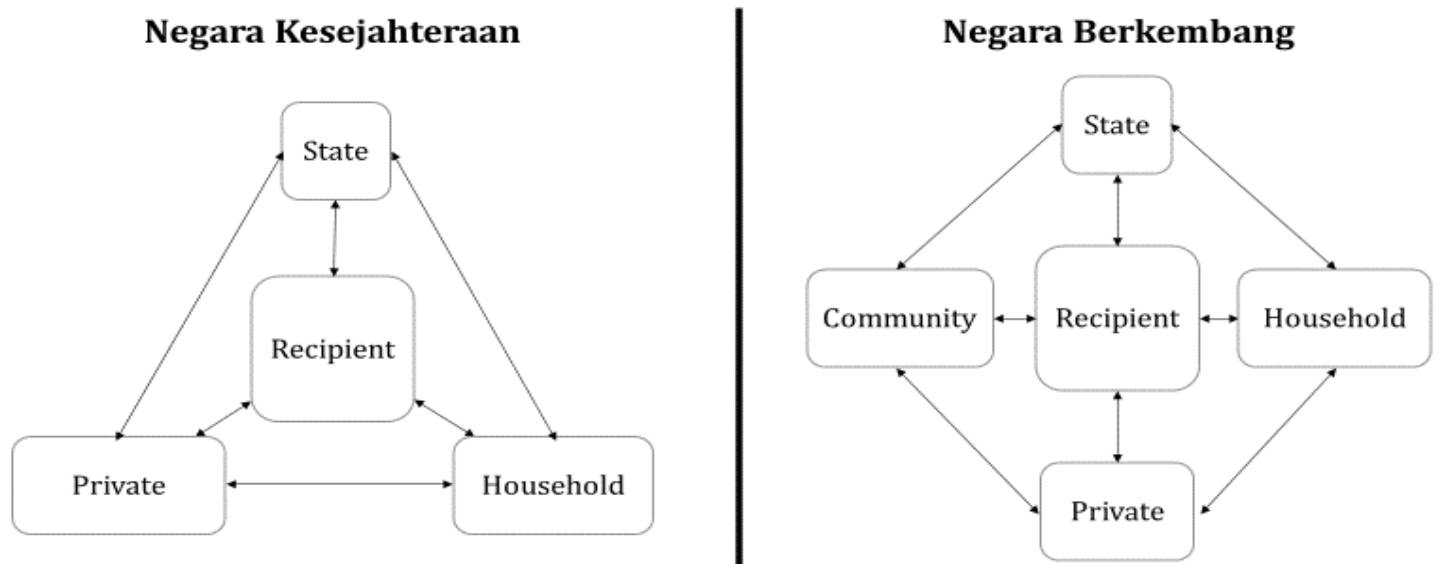

Sumber: Gough, 2004; Sumarto, 2017; Wood, 2004 
hingga sambatan (Sumarto, 2017). Semua hal itu merupakan upaya masyarakat dalam menyediakan kesejahteraan secara mandiri.

\section{Jaringan Dukungan Sosial sebagai Sumber Kesejahteraan Ketiga}

Argumen peran komunitas dalam konsep informal security regime juga bersinggungan dengan hadirnya jaringan dukungan sosial sebagai sumber kesejahteraan ketiga. Studi oleh Hill, Hirsch, \& Davis (2020) menunjukan bahwa rendahnya dukungan negara dan minimnya akses kepada pasar atas kesejahtaraan akan meninggalkan kelompok rentan pada ketidakpastian pendapatan. Dalam kondisi demikian, peran dari jaringan sosial seperti keluarga dan teman yang lebih luas akan menjadi sumber kesejahteraan alternatif. Seperti halnya dikatakan Sotiropoulos \& Bourikos (2014) bahwa ketika pemerintah mulai mengurangi perannya dalam penyediaan kesejahteraan, maka masyarakat masuk untuk menempati ruang baru yang tersedia. Peran jaringan ini menjadi sebuah bentukyang lebih signifikan dalam menyelamatkan kelompok rentan seperti pada keluarga dengan pendapatan yang rendah (Hill et al., 2020). Jaringan sosial tersebut dikatakan Canton (2018) sebagai seperangkat kumpulan individu yang saling terhubung satu sama lain dalam rangkaian hubungan. Jaringan dan kelompok ini kemudian membentuk ikatan informal baik di antara mereka maupun penerima manfaat dari kegiatannya (Sotiropoulos \& Bourikos, 2014).

Dalam kaitannya sebagai bagian dari sumber kesejahteraan, salah satu peran jaringan dukungan sosial adalah untuk meringankan beban kelompok rentan terutama pada masa kesulitan ekonomi. Seperti dijelaskan oleh Canton (2018) bahwa masa yang sulit seperti resesi ekonomi dan masa penghematan akan menjadikan peran dari jaringan dukungan sosial semakin relevan. Pasalnya, perubahan sosial ekonomi yang terjadi telah memberi efek pada masyarakat seperti adanya resesi, ketidakpastian pasar kerja, penghematan pemerintah, dan turunnya pendapatan (Canton, 2018). Pada kondisi demikian, masyarakat miskin akan menjadi kelompok yang paling terdampak lantaran peran pemerintah menjadi terbatas di tengah masa penghematan. Keterbatasan dukungan negara dalam memberikan jaminan bagi warganya ini kemudian akan menyebabkan masyarakat akan mencari sumber alternatif seperti adanya jaringan dukungan sosial.
Dalam masa krisis, beberapa literatur (Canton, 2018; Hill et al., 2020; Sotiropoulos \& Bourikos, 2014) berpendapat bahwa jaringan dukungan sosial dapat menjadi sebuah jaring pengaman di luar negara. Kehadiran jaring pengaman ini memiliki fungsi menjaga para kelompok terdampak agar tidak jatuh pada kondisi miskin. Sehingga, risiko-risiko yang ada akibat krisis ekonomi dapat ditanggulangi melalui peran dukungan sosial. Dukungan sosial dapat memberi dukungan keuangan dan emosional dalam masa krisis dan bertindak sebagai 'penyambung hidup' bagi beberapa keluarga. Memiliki dukungan pada masa kesulitan keuangan dapat bertindak sebagai jaring pengaman yang penting bagi mereka yang mengalami penurunan pendapatan (Hill et al., 2020:9). Hadirnya jaring pengaman dari dukungan sosial ini pun pada prosesnya memiliki bentuk yang bervariasi. Jaringan sosial informal dan kelompok swadaya muncul dan menjadi aktif dalam berbagai bentuk seperti pertukaran dan distribusi barang dan jasa, perawatan kesehatan, pendidikan, penyediaan makanan dan tempat tinggal (Sotiropoulos \& Bourikos, 2014:40), atau bahkan dalam bentuk uang tunai sekalipun (Canton, 2018:33).

Meskipun jaringan dukungan sosial ini dapat menjadi sumber kesejahteraan ketiga selama krisis, namun model demikian juga merupakan bentuk yang rapuh. Kerapuhan ini dapat dijabarkan dengan dua hal pokok. Pertama, dari segi sumber daya manusia yang ada, dengan asas kerelawanan model jaringan ini akan sangat mudah berubah. Tiap orang yang memberi dukungan dapat datang dan pergi dengan leluasa. Di satu sisi, individu yang memberi dukungan tersebut juga dapat masuk dalam kondisi kerentanan yang sama. Selain itu, jaringan sosial ini juga memiliki tantangan lain berupa sumber daya finansial yang tidak pasti. Sehingga, meskipun jaringan dukungan sosial dapat menjadi jaring pengaman yang berharga, namun pada praktinya hal ini merupakan sebuah model yang tidak permanen dan mudah berubah (Hill et al., 2020).

\section{Metode Penelitian}

Penelitian ini menggunakan desain penelitian kualitatif dengan varian studi kasus. Pendekatan tersebut digunakan untuk menganalisis gejalagejala sosial yang muncul di masyarakat. Selain itu, pendekatan studi kasus ini digunakan 
untuk memungkinkan penulis dalam menjawab pertanyaan penelitian 'bagaimana' (Baxter \& Jack, 2008). Lokasi penelitan ini berada di wilayah Daerah Istimewa Yogyakarta (DIY), khususnya di Kabupaten Bantul, Kabupaten Sleman, dan Kota Yogyakarta. Data penelitian dikumpulkan melalui wawancara terhadap informan, serta sumber sekunder berupa data statistik, berita, dan data relevan lainnya. Untuk menentukan informan, peneliti menggunakan metode purposive sampling, yang difokuskan pada aktor-aktor yang terlibat di jaringan Solidaritas Pangan Jogja. Selain itu, peneliti juga menggunakan metode tambahan snowball sampling untuk menemukan informan yang dapat memberikan informasi yang relevan guna memenuhi kelengkapan data. Total informan berjumlah enam orang yang terdiri dari koordinator lintas dapur, penanggungjawab dapur umum dan komunitas, serta relawan SPJ. Penelitian dilakukan sejak 26 Juni hingga 12 Juli 2020.

Berdasarkan rumusan pertanyaan, maka ruang lingkup penelitian difokuskan pada dinamika gerakan Solidaritas Pangan Jogja sebagai aktor alternatif dalam penyediaan kesejahteraan pada masa krisis pandemi COVID-19. Guna memperolah hasil penelitian yang sesuai dengan tujuan penelitian, maka teknik analisis data yang digunakan adalah deskriptif kualitatif. Dalam analisis kualitatif, langkah-langkah analisis yang sering digunakan untuk menafsirkan data adalah melalui (a) reduksi data, (b) kategorisasi, (c) penafsiran data, (d) menarik kesimpulan/verifikasi (Moleong, 2017). Kesimpulan yang diharapkan dalam penelitian ini merupakan jawaban atas pertanyaan penelitian yang telah dijelaskan sebelumnya mengenai bagaimana Solidaritas Pangan Jogja bergerak sebagai aktor alternatif dalam penyediaan kesejahteraan untuk pekerja informal dan kelompok rentan di tengah krisis pandemi COVID-19.

\section{Hasil}

Gerakan Solidaritas Pangan Jogja

Peran komunitas dalam upaya penyediaan kesejahteraan pada masa krisis akibat pandemi COVID-19 dapat dilihat dari munculnya gerakan SPJ. Tidak hanya melakukan aksi galang donasi dalam bentuk uang saja, SPJ bergerak dengan mendirikan dapur dan membuat makanan untuk dibagikan kepada masyarakat, khususnya para pekerja informal dan kelompok rentan yang ada di Daerah Istimewa Yogyakarta (DIY).

Awal mulanya, keberadaan SPJ didasari oleh kepedulian relawan terhadap masyarakat yang mengalami kesulitan ekonomi. Pada masa awal pandemi COVID-19, pemerintah mengeluarkan kebijakan physical distancing dengan menghimbau masyarakat untuk melakukan segala aktivitas dari rumah. Hal ini dilakukan untuk meminimalisir penyebaran COVID-19. Berbeda dari wilayah lain yang menerapkan Pembatasan Sosial Berskala Besar (PSBB), Pemerintah Daerah Istimewa Yogyakarta memilih untuk menetapkan status tanggap darurat bencana COVID-19 yang dikeluarkan melalui Surat Edaran Gubernur No.1/SE/ III/2020 Tentang Pelaksanaan Status Tanggap Darurat Bencana COVID-19 di DIY. Melalui surat tersebut, masyarakat dihimbau untuk tetap tenang, tidak berpegian dan menunda perjalanan baik ke luar kota maupun luar negeri, menunda kegiatan yang bersifat mengumpulkan banyak orang, serta melaksanakan budaya hidup bersih dan sehat sehingga dengan adanya aturan tersebut, jalanan dan ruang publik di Yogyakarta menjadi sepi. Hal ini kemudian berdampak pada kondisi ekonomi masyarakat, utamanya masyarakat yang bekerja di sektor ekonomi informal.

"Di sini banyak yang mengeluh. Misal ada yang bekerja di home industry, kan sepi penjualannya. Sementera diistirahatkan. Yang jualan pun sama. Warga tidak ada pemasukan. Banyakyang mengeluh soal itu." (Dika, Wawancara 2 Juli 2020).

Melihat kondisi tersebut, muncul berbagai inisiatif dari berbagai kalangan. Salah satunya adalah Syafiatudina (Dina) yang menggalang dana dari teman-temannya untuk dibelikan nasi bungkus yang kemudian dibagikan kepada masyarakat yang mengalami kesulitan ekonomi. Upaya yang dilakukan Dina ini juga berangkat dari permasalahan banyaknya masyarakat terdampak yang belum menerima bantuan dari pemerintah. Seperti diketahui, pemerintah merespon kondisi krisis ini dengan memberikan bantuan sosial melalui berbagai program. Namun, masyarakat melihat bahwa ada banyak permasalahan dalam pemberian bantuan sosial.

"Bantuan yang dari pemerintah itu tidak merata. Ada juga yang dapat, tapi tidak 
Saqib Fardan Ahmada, Fernandito Dikky Marsetyo, Rizqy Anita Putri - Solidaritas Pangan Jogja sebagai Aktor Alternatif Penyedia Kesejahteraan di Masa Krisis Pandemi COVID-19

kunjung cair. Ada pula yang seharusnya mendapatkan, tapi malah yang mendapatkan justru orang lain (orang yang tidak membutuhkan). Respon orang-orang beragam menyikapi soal itu, tapi kalau menurut saya, banyak bantuan yang salah sasaran. Yang seharusnya mendapatkan, malah tidak mendapatkan. Karena corona, semuanya terdampak, semuanya kena." (Atik, Wawancara 2 Juli 2020),

Beberapa kelompok masyarakat juga sempat mendatangi instansi pemerintah untuk mendapatkan bantuan. Salah satunya Damar yang merupakan koordinator pemulung di Kampung Wonocatur. Ia sempat mendatangi Dinas Sosial Daerah Istimewa Yogyakarta untuk meminta bantuan bahan kebutuhan pokok. Namun, usahanya tidak membuahkan hasil karena mesti melewati prosedur birokrasi yang rumit. Merespons situasi tersebut, Dina mulai berjejaring dengan aktivis dan relawan lain yang melakukan kegiatan serupa. Mereka menyadari bahwa ada sebuah kebutuhan untuk mendirikan dapur umum untuk membantu masyarakat yang terdampak pandemi, utamanya dalam hal makanan. Berawal dari kesadaran tersebut, inisiasi untuk membuat jaringan SPJ terbentuk. Jejaring semacam ini bukan merupakan hal baru. Jejaring ini muncul seiring dengan berkembangnya gerakan aktivisme di DIY yang dilakukan oleh berbagai elemen masyarakat, mulai dari mahasiswa, aktivis, komunitas, LSM, hingga organisasi non pemerintah. Sebagai contoh, gerakan yang sebelumnya hadir adalah gerakan penolakan Bandara New Yogyakarta International Airport (NYIA). Terbentuknya SPJ tidak dapat dilepaskan dari gerakan tersebut. Sebab mereka yang mengisi gerakan-gerakan tersebut telah berjejaring satu sama lain sebelumnya.

"Relasinya sudah ada dan kuat sebelumnya. SPJ berhutang dengan gerakan-gerakan sebelumnya yang sudah pernah ada." (Dina, Wawancara Juli 2020).

Jejaring yang sudah terbentuk dapat dilihat dari adanya hubungan antara Paguyuban Petani Lahan Pantai (PPLP) Kulonprogo dengan beberapa aktivis di SPJ. Saat gerakan penolakan Bandara New Yogyakarta International Airport (NYIA) berlangsung, PPLP Kulonprogo memberikan bantuan makanan kepada para aktivis. Hubungan tersebut terus terjalin hingga saat SPJ diinisiasi. Saat inisiatif tersebut muncul, PPLP Kulonprogo turut berkontribusi memberikan bantuan berupa sayuran sebagai bentuk solidaritas.

"Beberapa tahun kemudian komunikasinya tetap intens. Mereka (PPLP Kulonprogo) juga bisa bantunya ya itu. Ngasih bantuan makanan. Bagi mereka ini bentuksolidaritas. Mereka bantu Jogja yang lagi kesulitan makanan." (Andrew, Wawancara 12 Juli 2020).

Kehadiran SPJ juga menghubungkan beberapa kelompok yang sebelumnya tidak terhubung satu sama lain. Sebagai contoh, kelompok pemulung di Wonocatur yang sebelumnya tidak memiliki hubungan dengan para aktivis yang terlibat dalam SPJ. Namun, adanya pandemi COVID-19 dan munculnya inisiatif untuk mendirikan dapur umum di Wonocatur, membuat jejaring antara SPJ dan kelompok pemulung Wonocatur terbentuk.

Jaringan dalam gerakan SPJ kemudian mengorganisir sumber daya yang ada dan dimiliki untuk mendirikan dapur umum. Tidak hanya aktivis saja, namun juga terdapat seniman, petani, dan kelompok masyarakat lainnya. Semua pihak yang terlibat dapat saling mengkonsolidasikan apa yang masingmasing mereka miliki satu sama lain. SPJ menyebut apa yang dilakukannya merupakan pengorganisasian berbasis jaringan. Model ini dilandasi oleh sebuah basis ide mengenai tindakan kolektif "apa yang bisa dilakukan untuk membantu masyarakat yang terdampak pandemi?". Basis ini tidak didasarkan pada latar belakang ideologi, politik, maupun SARA (suku, ras, dan agama). Dengan demikian, siapa saja dapat terlibat dalam jaringan. Semangat yang melandasi gerakan SPJ adalah semangat "rakyat bantu rakyat". Sebab, bagi SPJ pada situasi krisis akibat pandemi COVID-19, yang bisa dilakukan untuk bertahan adalah dengan bersolidaritas sesama masyarakat. Selain itu, mereka yang berada dalam jaringan SPJ sepakat bahwa hadirnya gerakan ini adalah untuk menciptakan kemandirian bersama. Bahwa dalam merespon situasi pandemi COVID-19, masyarakat tidak menggantungkan nasib kepada pihak yang lebih memiliki kuasa, tetapi masyarakat dapat mencukupi kebutuhan melalui tindakan kolektif. 
SPJ berupaya membantu masyarakat rentan dengan mencukupi kebutuhan makanan berupa nasi bungkus. Setidaknya ada dua alasan mengapa SPJ memilih untuk mengupayakan kebutuhan tersebut. Pertama, makanan adalah kebutuhan paling mendasar dan bentuk respons paling awal yang dibutuhkan oleh masyarakat ketika kondisi krisis melanda. Kedua, membuat semacam jaring pengaman dengan makanan sebagai respons awal.

"Paling tidak dengan mencukupi kebutuhan dasar seseorang (makanan), satu persoalan sudah selesai. Orang yang dibantu punya kesempatan untuk memikirkan hal yang lain. Dia punya waktu untuk cari cara gimana menyambung hidup. Orang bisa selamat hari itu." (Dina, Wawancara 7 Juli 2020).

Hasilnya, sejak berdiri pada Bulan Maret 2020, SPJ telah memiliki sebelas dapur dari yang awalnya hanya terdiri dari tiga dapur. Dapur dalam jaringan SPJ tersebar di berbagai titik di wilayah DIY. Jejaring tersebut juga telah menghasilkan dua jenis dapur, yaitu dapur umum dan dapur komunitas.

Perbedaan kedua jenis dapur tersebut terletak pada sasaran penerima bantuan makanan. Dapur umum adalah dapur yang memproduksi dan mendistribusikan makanan kepada pekerja informal di jalan dan ruang publik lainnya. Sedangkan dapur komunitas adalah dapur yang dikelola oleh warga atau komunitas untuk memenuhi kebutuhan makanan, khususnya mereka yang berada dalam kondisi rentan di wilayahnya. Sebagai contoh, dua dapur komunitas yang berada dalam jaringan SPJ adalah Dapur Wonocatur dan Dapur Cepokojajar. Di Dapur Wonocatur makanan dibagikan kepada para pemulung. Sedangkan, Dapur Cepokojajar menyasar lansia, difabel, dan pengangguran sebagai sasaran penerima bantuan. Seperti yang dijelaskan sebelumnya, dapur komunitas melakukan pendataan, sehingga sasaran penerima bantuan makanan lebih jelas dan tercatat. Itulah perbedaan antara dapur umum dan dapur komunitas.

\section{Alur Kerja Solidaritas Pangan Jogja}

Secara umum, SPJ melakukan aktivitasnya melalui empat tahapan, yakni: 1) Galang donasi, 2) Distribusi donasi ke tiap-tiap dapur, 3) Pembuatan makanan di dapur, dan 4) Penyaluran makanan kepada kelompok sasaran. Untuk mendukung aktivitas tersebut, maka terdapat pembagian tugas agar aktivitas berjalan dengan baik. Pembagian tugas setidaknya terdiri dari tiga bagian, yaitu: 1) Penanggungjawab (PJ) Dapur, 2) Administrasi, dan 3) Relawan. PJ Dapur memiliki tanggung jawab untuk memastikan operasional dapur dan menjadi koordinator utama dari sebuah dapur (baik dapur umum maupun komunitas). Tim Administrasi memiliki tugas untuk menghimpun dan mengelola donasi, berkoordinasi dengan tiap-tiap dapur, serta menjadi penghubung antara relawan dengan dapur. Sedangkan relawan sifatnya lebih terbuka dan dapat membantu berbagai aktivitas tiap-tiap dapur, seperti memasak maupun membagikan makanan.

Tabel 1

Lokasi Dapur Umum dan Dapur Komunitas Solidaritas Pangan Jogja

\begin{tabular}{|c|c|c|c|}
\hline No. & Nama Dapur & Jenis Dapur & Alamat \\
\hline 1. & Dapur Pasar Gamping & Umum & $\begin{array}{l}\text { Perumahan Ambarketawang Permai, Gamping Kidul, RT 3/RW 19, } \\
\text { Gamping, Sleman }\end{array}$ \\
\hline 2. & Dapur Prawirotaman & Umum & Reene'o Guesthouse, Brontokusuman, MG III/379, Yogyakarta \\
\hline 3. & Dapur Seyegan & Umum & Araya Stable, Dusun Klaci II, Desa Margoluwih, Seyegan, Sleman \\
\hline 4. & Dapur Wonocatur & Komunitas & Gang Rukun, Jalan Wonocatur, RT 4/RW 2, Yogyakarta \\
\hline 5. & Dapur Cepokojajar & Komunitas & $\begin{array}{l}\text { Kedaiaman Pak Slamet, Pak Eko, Pak Yono, Cepokojajar, Rt 2, } \\
\text { Sitimulyto, Piyungan, Bantul }\end{array}$ \\
\hline 6. & Dapur Ngadiwinatan & Umum & Ngadiwinatan 1/249 Yogyakarta \\
\hline 7. & Dapur Caturtunggal & Umum & Jalan Wira Jaya No. 135, Gejayan, Condongcatur, Depok, Sleman \\
\hline 8. & Dapur Balirejo & Komunitas & Gang Kencana, Muja Maju, Yogyakarta \\
\hline 9. & Dapur Bongsuwung & Komunitas & Bongsuwung, Gedongtengen, Barat Stasiun Tugu, Yogyakarta \\
\hline 10. & Dapur Keparakan & Komunitas & Keparakan Kidul, Kotagede, Yogyakarta \\
\hline 11. & Dapur Sembungan & Umum & Gang Ramawijaya, Sumbungan, RT 33, Bangunjiwo, Kasihan, Bantul \\
\hline
\end{tabular}

Sumber: Solidaritas Pangan Jogja, 2020 


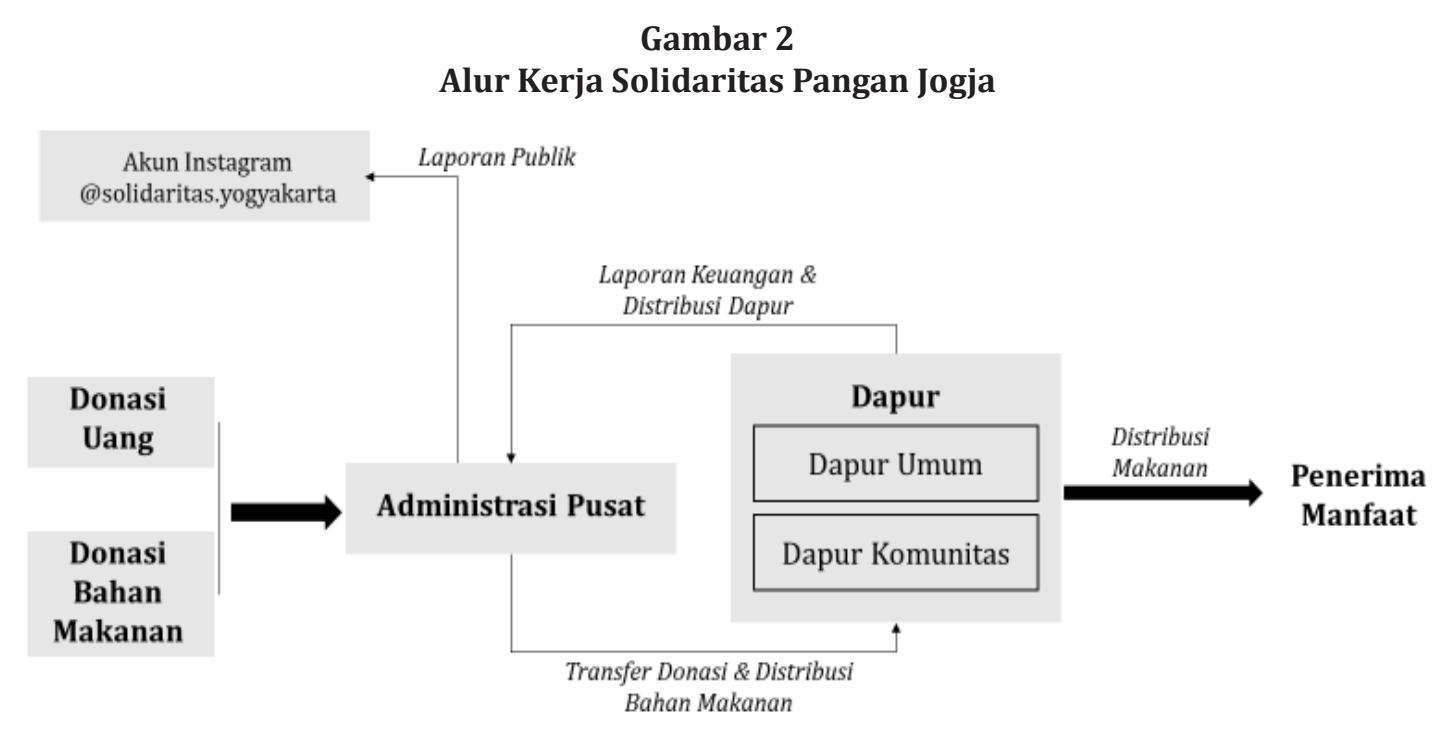

Sumber: Olahan Peneliti, 2020

Dalam menjalankan aktivitasnya, SPJ memanfaatkan media sosial berupa Instagram (@solidaritas.yogyakarta) sebagai sarana publikasi dan membangun jejaring. Informasi yang bertujuan untuk menggalang donasi, laporan distribusi, dan kegiatan dapur dibagikan melalui Instagram. Hal ini juga dimaksudkan sebagai bentuk transparansi dan akuntabilitas kepada masyarakat umum. Proses penggalangan donasi juga terbuka untuk umum, sehingga siapa saja dapat memberikan donasi. SPJ memanfaatkan dua rekening bank dan layanan pembayaran digital seperti Go-Pay dan OVO sebagai wadah donasi. Masyarakat maupun komunitas yang telah mengirimkan donasi biasanya diminta untuk melakukan konfirmasi kepada narahubung SPJ.

Secara rutin, donasi didistribusikan ke setiap dapur menggunakan sistem transfer bank. Tujuannya adalah untuk memudahkan pencatatan arus uang dan pelaporan kepada publik. Tiap-tiap dapur akan mendapatkan uang sebesar Rp500.000,00 - Rp700.000,00 per minggu. Besaran jumlah uang tersebut disesuaikan dengan kebutuhan setiap dapur. Jika terdapat kebutuhan mendesak, PJ Dapur dapat melaporkannya kepada tim administrasi.

Tidak hanya menggalang donasi, SPJ juga menguatkan jejaring antar komunitas. Contohnya, mereka mendapatkan bantuan dari Paguyuban Petani Lahan Pantai (PPLP) Kulonprogo. Sampai Bulan Juli 2020, PPLP Kulonprogo telah mengirimkan sayuran segar sebanyak 16 kali. Sama halnya dengan uang, donasi tersebut didistribusikan langsung sesuai dengan kebutuhan masing-masing dapur. Selain itu, SPJ juga mendorong setiap dapur untuk membangun jaringan agar kebutuhan dapur dapat terpenuhi. Hal ini dimaksudkan agar dapur memiliki daya dan memiliki kemampuan untuk berjejaring secara mandiri.

Proses pembuatan makanan menjadi tanggung jawab masing-masing dapur. Kesebelas dapur yang ada memiliki otonomi dalam pengelolaan dapur. Setiap dapur dapat menentukan cara kerja, menu makanan, lokasi distribusi makanan, hingga menentukan siapa penerima manfaatnya. Setiap dapur dapat menghasilkan 50-200 makanan per hari untuk dibagikan. Makanan yang telah diproduksi kemudian dibagikan ke area sekitar dapur masing-masing. Umumnya, makanan ini dibagikan kepada pekerja informal, pemulung, pedangang kecil, difabel, lansia, dan lainlain. Walaupun setiap dapur diberi otonomi untuk mengelola dapur, mereka diminta untuk memberikan laporan kepada tim administrasi setiap hari.

\section{Dinamika Solidaritas Pangan Jogja}

Perjalanan SPJ dalam upaya untuk membantu kebutuhan makanan masyarakat rentan bukan tanpa tantangan dan hambatan. Selama beraktivitas sejak Bulan Maret - Juli, SPJ mendapatkan tindakan intimidatif dan pengawasan yang berlebihan dari aparat pemerintah. Sebagai contoh, pada tanggal 17 April 2020, para relawan dalam jaringan 
SPJ yang sedang melakukan rapat di Kantor Wahana Lingkungan Hidup (WALHI), tibatiba dibubarkan paksa oleh seseorang yang mengaku dari aparat pemerintah. Kejadian ini membuat SPJ mengirimkan surat terbuka yang ditujukan kepada Presiden Joko Widodo. Surat tersebut berisi cerita mengenai tindakantindakan intimidatif yang dialami oleh SPJ dan permohonan kepada presiden agar menginstruksikan penghentian tindakan tersebut. Kejadian ini kemudian menimbulkan kontroversi diantara SPJ dengan aparat pemerintah. Dilansir dari laman Tirto.id (21 April 2020), pihak kepolisian membantah telah melakukan pembubaran paksa di Kantor WALHI. Pihak kepolisian berpendapat bahwa tindakan yang dilakukan merupakan bentuk respons atas keresahan masyarakat setempat, sebab kegiatan di kantor WALHI sering mendatangkan banyak orang dari berbagai daerah di tengah aturan pembatasan sosial.

Tantangan lainnya adalah pasang surut donasi. Jumlah donasi yang diterima SPJ beragam dan jumlahnya bervariasi, mulai dari Rp 20.000,- sampai Rp10.000.000,00. Pada masa awal pandemi COVID-19 ramai dibicarakan, donasi yang masuk cukup masif. Tercatat sejak Maret 2020, total donasi yang masuk mencapai 100 juta rupiah. Puncaknya adalah pada saat Bulan Mei 2020, tepatnya saat Ramadhan dan Hari Raya Idul Fitri. Memasuki Bulan Juni dan munculnya wacana new normal dari pemerintah, jumlah donasi kemudian berangsur surut. Situasi yang dinilai sudah tidak darurat menjadi salah satu faktor surutnya donasi. Selain itu, tidak jarang donatur dan relawan SPJ juga berada dalam masa sulit.

"Pasang surut donasi ini salah satu problemnya adalah kondisi ekonomi makin ngga pasti, donatur kami adalah orang yang aku percaya bahwa ekonominya pasti terdampak. Jadi itu mungkin salah satu faktor. Faktor yang lain adalah situasi feeling dipublik ini sudah ngga terlalu darurat lagi. Aku menyebutnya sebagai normalisasi krisis gitu. Itu dinormalkan. Dan itu memengaruhi orang untuk: oke kita bisa kerja dan berhenti mengirim bantuan." (Dina, Wawancarai 7 Juli 2020)

Besarnya jumlah donasi yang masuk juga berbanding lurus dengan jumlah pengeluaran.
Walaupun jumlah donasi yang diberikan ke tiap-tiap dapur disesuaikan dengan kebutuhan dapur, jumlahnya dapat dikatakan terbatas. Permasalahan finansial merupakan faktor utama yang paling dirasakan dalam dinamika gerakan SPJ.

"Kita harus mikir banget dengan uang yang ada, paling sulit ya arena finansial untuk bertahan." (Ola, Wawancara 10 Juli 2020)

Kondisi tersebut membuat setiap dapur dapat mencari sumber pemasukan lain agar tetap beroperasi. Contohnya dengan menerima donasi dari komunitas lain, mengadakan diskusi terbuka, hingga membuat merchandise. Namun, jumlah donasi yang semakin menipis dan situasi yang dianggap sudah mulai pulih membuat tiap-tiap dapur membuat keputusan untuk menghentikan aktivitas dapur. Salah satu contohnya adalah Dapur Wonocatur yang merupakan dapur komunitas pemulung, membuat keputusan untuk menghentikan aktivitasnya. Alasannya adalah para pemulung mulai dapat beraktivitas kembali dan donasi yang ada dapat dimanfaatkan untuk dapur lain yang masih membutuhkan. Namun, ada pula dapur di lokasi lain yang belum siap untuk berhenti dan merasa bahwa dapur umum masih dibutuhkan

"Kalau dapur ini tutup, saya juga kepikiran simbah-simbah ini. Banyak lansia yang menggantungkan pada dapur ini." (Atik, Wawancara 9 Juli 2020)

Terakhir, jumlah relawan yang tidak menentu juga menjadi persoalan lain. SPJ yang menggunakan model pengorganisasian berbasis jaringan membuat relawan dapat datang dan pergi dengan mudah. Walaupun dapat dipandang sebagai suatu kekuatan dengan menyediakan ruang bagi siapa saja untuk berkontribusi menjadi relawan, hal ini dapat menjadi suatu kelemahan, terutama dalam hal konsistensi. Tidak jarang, relawan juga memiliki aktivitas, permasalahan, atau dinamikanya masing-masing.

"Tidak tahu mereka sibuk sama dinamika mereka sendiri atau mereka mau istriahat saya tidak tahu. Tapi itu udah biasa sih pola seperti itu." (Dika, Wawancara 4 Juli 2020). 


\section{Diskusi}

Seperti diuraikan sebelumnya, SPJ dapat hadir mendistribusikan makanan kepada pekerja informal dan kelompok rentan di DIY. Di masa krisis akibat pandemi COVID-19, SPJ dapat menjadi aktor yang secara cepat membantu masyarakat dalam urusan pangan. Peran ini menjadikan SPJ dapat menjadi aktor alternatif di tengah keterbatasan pemerintah dalam menyediakan jaring pengaman di tengah masa krisis. Persoalan data yang tidak aktual dan persoalan rumitnya alur birokrasi membuat bantuan pemerintah tidak dapat merespon dengan cepat kondisi yang ada. Hal seperti ini terlihat dari cerita Kartika Damar yang mendatangi Dinas Sosial DIY untuk meminta bantuan bahan makanan pokok namun gagal. Akhirnya Damar dan para pemulung lainnya bisa mendapat bantuan setelah menghubungi pihak SPJ. Persoalan lain seperti bantuan dari pemerintah yang tidak tepat sasaran juga nyata terjadi. Hal ini dapat dilihat dari uraian Ibu Atik yang merasakan secara langsung persoalan ini di sekitar dapur Cepokojajar.

Permasalahan ini menjadi gambaran bahwa hadirnya SPJ sebagai jaringan sosial dapat menjadi aktor alternatif di tengah permasalahan bantuan dari pemerintah. Hal ini senada dengan apa yang diuraikan Wood (2004) dan Gough (2004) mengenai informal security regime, bahwa dalam kondisi ketika masyarakat kesulitan untuk memenuhi kesejahteraanya dari negara atau pasar, maka mereka akan mengandalkan peran akses sumber kesejahteraan yang lain seperti dari hubungan keluarga dan pertemanan. Selain itu, kehadiran SPJ juga dapat menjadi gambaran akan pentingnya sumber daya sosial dan kultural di tingkat komunitas dan keluarga. Semangat "rakyat bantu rakyat" yang digaungkan SPJ juga turut menunjukan pentingnya saling tolong-menolong antar sesama masyarakat. Penjabaran ini menunjukkan sekilas wajah rezim kesejahteraan di Indonesia, bahwa negara tidak dapat berdiri sendiri dalam penyelenggaraan perlindungan sosial (Yuda, 2017).

Bersinggungan dengan penjelasan tersebut, SPJ juga telah menjadi sebuah jaringan dukungan sosial yang dapat menjadi sumber kesejahteraan ketiga di masa krisis akibat pandemi. SPJ dapat menjadi gerakan solidaritas pangan yang masif karena sudah ada jejaring yang terbentuk sebelumnya. Relasi yang terbentuk dalam jejaring ini menjadikan momentum krisis dapat direspons dengan cepat melalui gerakan SPJ. Tidak hanya secara cepat, relasi yang sudah terbentuk ini juga menjadikan SPJ lebih mudah dalam mendapatkan sokongan donasi untuk dapur-dapur. Bukan hanya soal bantuan uang saja, bantuan berupa bahan makanan juga diberikan karena relasinya dengan PPLP di Kulonprogo. Dengan kondisi demikian, tidak heran dalam prosesnya SPJ telah memiliki hingga sebelas dapur yang tersebar di Sleman, Bantul, dan Yogyakarta. Kesebelas dapur ini juga memiliki krakteristik yang beragam. Mulai dari dapur umum yang mendistribusikan makanan kepada orang-orang di jalanan secara acak. Terdapat juga dapur komunitas yang secara spesifik mendistribusikan makanan ke kelompok tertentu seperti kelompok pemulung (Dapur Wonocatur), kelompok lansia dan difabel (Dapur Cepokojajar), hingga kelompok PSK (Dapur Bongsuwung).

Dengan demikian, jaringan yang dimiliki SPJ dapat berperan sebagai pemberi dukungan kepada banyak kelompok terdampak krisis di Yogyakarta. Bantuan yang diberikan tidak terlepas dari jejaring yang mendasari berdirinya SPJ. Keterhubungan antar relasi, baik individu maupun kelompok menjadikan SPJ sebagai sumber kesejahteraan ketiga di tengah keterbatasan bantuan pemerintah. Kekuatan ini yang menjadikan SPJ telah bertransformasi menjadi sebuah jaringan dukungan sosial. Sejalan dengan apa yang diuraikan (Sotiropoulos \& Bourikos, 2014) bahwa jaringan di SPJ telah membentuk ikatan informal baik di antara mereka maupun penerima manfaat dari kegiatannya. Selain itu, proses distribusi makanan di SPJ yang masif dan cepat memberi gambaran bahwa peran jaringan dukungan sosial dapat menjadi sebuah bentuk yang lebih signifikan dalam menolong kelompok rentan (Hill et al., 2020) dalam masa kesulitan ekonomi (Canton, 2018).

Seperti diketahui, adanya pandemi COVID-19 telah membuat masyarakat khususnya para pekerja informal dan kelompok rentan menghadapi bayang-bayang risiko ekonomi. Dalam merespon situasi tersebut, dibutuhkan sebuah jaring pengaman agar mereka tidak semakin jatuh dalam jurang kemiskinan. Di tengah terbatasnya bantuan pemerintah dalam penyediaan jaring pengaman sosial, SPJ sebagai jaringan dukungan sosial bertindak untuk memenuhi kebutuhan makanan bagi para pekerja 
informal dan kelompok rentan. Hal ini dilakukan SPJ dengan pemikiran bahwa makanan adalah kebutuhan paling dasar bagi keberlangsungan hidup seseorang. Selain itu, pendistribusian makanan juga dapat menjadi respon paling awal bagi para kelompok terdampak di tengah masa yang sulit. Hal ini sejalan dengan apa yang disampaikan Dina tentang pentingnya bantuan makanan bagi para kelompok terdampak, bahwa paling tidak dengan memenuhi kebutuhan dasar berupa makanan, seseorang bisa selamat hari itu. Sehingga, ketika satu persoalan sudah selesai, orang tersebut dapat memikirkan hal lain untuk menyambung hidup mereka. Peran SPJ dalam melakukan distribusi makanan dengan demikian dapat menjadi sebuah jaring pengaman yang penting bagi masyarakat rentan di Yogyakarta. Bahwa jaringan dukungan sosial dapat memberi bantuan dalam masa krisis dan bertindak sebagai 'penyambung hidup' bagi para kelompok terdampak sehingga, risiko-risiko awal akibat masa kesulitan ekonomi seperti adanya kelaparan dan kekurangan makanan dapat segera diatasi melalui hadirnya SPJ.

Namun demikian, meskipun gerakan yang dilakukan SPJ dapat memberikan bantuan yang cepat, utamanya dalam penyediaan makanan, gerakan semacam ini juga memiliki kerapuhan. Setidaknya, ada dua hal pokok yang membuatnya rapuh. Pertama, dari sisi sumber daya manusia yang terlibat dalam jaringan oleh karena kesibukan dan kegiatan relawan masing-masing membuat pengelolaan dapur tidak dapat terus mengandalkan orang-orang yang sama. Hal ini dapat dilihat dari pernyataan Dika mengenai cerita Dapur Wonocatur. Asas kerelawanan dan model jaringan sosial berbasis ide kolektif membuat setiap individu maupun kelompok yang terlibat dan memberikan dukungan dapat datang dan pergi dengan mudah. Walaupun dapat dipandang sebagai suatu kekuatan dengan memberikan ruang bagi siapa saja untuk terlibat, tidak lantas membuat gerakan dapat bertahan lama. Tak jarang, mereka yang berada dalam jaringan SPJ juga berada dalam kondisi rentan, baik dalam hal finansial maupun dinamika layaknya manusia pada umumnya.

Selain itu, jaringan sosial ini juga memiliki tantangan lain berupa sumber daya finansial yang tidak pasti. Seperti keterangan Ola sebagai admin keuangan bahwa sejak Maret - Juli 2020, SPJ mengalami pasang surut donasi. Ketika masa awal pandemi COVID-19, donasi yang masuk jumlahnya relatif mencukupi. Namun, memasuki bulan Juni dan situasi yang dinilai sudah tidak darurat membuat jumlah donasi berangsur turun. Kondisi ini berusaha diatasi oleh beberapa PJ dapur yang berusaha mencari sumber pemasukan lain agar dapur tetap dapat beroperasi. Sumber pemasukan lain ini diperoleh melalui berbagai macam cara mulai dari menjual merchandise hingga membuat diskusi terbuka. Akan tetapi, jumlah donasi yang semakin menipis membuat beberapa dapur memutuskan untuk menghentikan aktivitas dapur dan mengalihkan donasi yang masih ada ke dapur yang masih beroperasi.

Kondisi yang dialami SPJ ini menjadi gambaran bahwa praktik jaringan dukungan sosial yang dilakukan SPJ bukan tanpa persoalan. Meski dapat menjadi sumber daya kesejahteraan alternatif di masa krisis, model demikian tetap saja memiliki titik kerapuhan. Dinamika sumber daya manusia dan finansial di SPJ yang mendasari argumen penulis bahwa praktik jaringan dukungan sosial merupakan sebuah model yang tidak permanen dan mudah berubah.

\section{Kesimpulan}

Tulisan ini berusaha menjelaskan bagaimana SPJ muncul sebagai aktor alternatif penyedia kesejahteraan berbasis jaringan sosial yang muncul di tengah keterbatasan negara dalam menyediakan jaring pengaman saat krisis. Penelitian ini menunjukkan bahwa gerakan SPJ dapat hadir sebagai aktor alternatif penyedia kesejahteraan di masa krisis pandemi COVID-19. Secara lebih rinci, tulisan ini memunculkan beberapa intisari pembahasan.

Pertama, bahwa ikatan antar relasi, baik individu maupun kelompok di SPJ dalam prosesnya telah bertransformasi menjadi sebuah jaringan dukungan sosial. Bentuk jaringan dukungan sosial dalam SPJ ini berperan sebagai sumber kesejahteraan lain di luar negara. Ketika berbagai skema jaring pengaman yang diberikan pemerintah belum sepenuhnya mampu memenuhi kebutuhan masyarakat, SPJ hadir sebagai aktor alternatif penyedia kesejahteraan. Apa yang dilakukan SPJ ini menjadi upaya resiliensi masyarakat dalam merespon krisis yang tengah melanda.

Kedua, peran sebagai sumber kesejahteraan alternatif ini secara lebih spesifik dapat dilihat melalui distribusi makanan yang dilakukan SPJ. Pemenuhan kebutuhan makanan ini dilakukan 
SPJ sebagai upaya memenuhi kebutuhan dasar para kelompok terdampak. Dengan adanya bantuan makanan ini, paling tidak masyarakat terdampak ini dapat menyambung hidup dan dapat memikirkan hal lain. Hal ini menjadikan distribusi makanan SPJ menjadi jaring pengaman di tengah kesulitan ekonomi yang melanda.

Ketiga, meskipun demikian, keberlangsungan praktik jaringan dukungan sosial seperti SPJ bukan berarti tanpa kekurangan. Meskipun dapat melakukan distribusi makanan secara masif dan cepat, namun terdapat beberapa kerapuhan yang ada dalam SPJ. Hal ini dapat dilihat dalam hal sumber daya manusia dan dan sumber daya finansial. Jaringan di SPJ yang bersifat cair menjadikan para relawan dapat mudah untuk masuk dan keluar. Selain itu, sokongan dana yang menggantungkan pada donasi masyarakat menjadikan kondisi finansial SPJ cukup dinamis. Dinamika tersebut membuat praktik jaringan dukungan sosial seperti SPJ merupakan sebuah model yang tidak permanen dan mudah berubah.

\section{Referensi}

Alkire, S., Dirksen, J., Nogales, R., \& Oldiges, C. (2020, April). Multidimensional Poverty and COVID-19 Risk Factors: A Rapid Overview of Interlinked Deprivations accross 5.7 Billion People (OPHI Briefing 53). https://ophi.org. uk/wp-content/uploads/B53_Covid-19_ vs3-2_2020_online.pdf. accessed on 20 July 2020.

Andersen, G. E. (1990). The Three World of Welfare Capitalism. Cambridge: Polity Press.

Asosiasi Business Development Services Indonesia. (2020, 13 April). UMKM Crisis Center. https://www.abdsi.id/umkm-crisiscenter. accessed on 20 July 2020.

Badan Pusat Statistik. (2020). Tinjauan Big Data terhadap Dampak COVID-19. https:// www.bps.go.id/publication/2020/06/01/ effd7bb05be2884fa460f160/tinjauan-bigdata-terhadap-dampak-covid-19-2020.html. accessed on 11 September 2020.

Bagus, A. P., N, A., Fathin, A., Ranggajati, A., Anindya, D. W., Ratih, D. S., ... Murwani, Y. W. (2020). Melindungi Pekerja Rentan di Masa (dan Pasca) Pandemi Covid-19. http:// map.ugm.ac.id/wp-content/uploads / sites/290/2020/04/Melindungi-PekerjaRentan-di-Masa-dan-Pasca-Pandemi-Covid19-kompres.pdf. accessed on 21 July 2020.
Baxter, P., \& Jack, S. (2008). Qualitative Case Study Methodology : Study Design and Implementation. The Qualitative Report.

Canton, J. (2018). Coping with hard times: The role that support networks play for lone mother families in times of economic crisis and government austerity. Families, Relationships and Societies, 7(1), pp. 23-38. doi: 10.1332/204674316X14651146433 919.

Consuello, Y. (2020). Analisis Efektifitas Kartu Pra-kerja di Tengah Pandemi Covid-19. Adalah: Buletin Hukum Dan Keadilan, 4 (1), pp. 93-100. doi: 10.15408/adalah. v4i1.15479.

Gough, I. (2004). Welfare regimes in development contexts: A global and regional analysis. In Insecurity and Welfare Regimes in Asia, Africa and Latin America: Social Policy in Development Contexts. doi: 10.1017/ CB09780511720239.003.

Hill, K., Hirsch, D., \& Davis, A. (2020). The Role of Social Support Networks in Helping Low Income Families through Uncertain Times. Social Policy and Society, 1-16. doi: 10.1017/ S1474746420000184.

Indikator Politik Indonesia. (2020). Persepsi Publik Terhadap Penanganan COVID-19, Kinerja Ekonomi danImplikasiPolitiknya. https://indikator.co.id/wpcontent/ uploads/2020/07/Rilis_surnas_07juni2020. pdf. accessed on 23 July 2020.

Indonesia Corruption Watch. (2020, April 27). Tunda dan Kaji Ulang Program Prakerja. https://antikorupsi.org/id/article/tundadan-kaji-ulang-program-prakerja. accessed on 23 July 2020.

Juaningsih, I. N. (2020). Analisis Kebijakan PHK Bagi Para Pekerja Pada Masa Pandemi Covid-19 di Indonesia. ADALAH: Buletin Hukum \& Keadilan, 4(1), 189-196. doi: 10.15408/adalah.v4i1.15764.

Kementerian Ketenagakerjaan. (2020, April 22). Menaker: Badai Pasti Berlalu, Panggil Kembali Pekerja yang ter-PHK Nanti. https://www.kemnaker.go.id/news/detail/ menaker-badai-pasti-berlalu-panggilkembali-pekerja-yang-ter-phk-nanti. accessed on 21 July 2020.

Knowledge Sector Initiative. (2020, April 14). Menekan Dampak Covid-19: Jaring Pengaman Sosial untuk Kelompok. https:// www.ksi-indonesia.org/id/insights/ 
detail/1277-menekan-dampak-covid-19jaring-pengaman-sosial-untuk-kelompokmarginal. accessed on 22 July 2020.

Lembaga Ilmu Pengetahuan Indonesia. (2020, Juni 30). Survei Kinerja UMKM di Masa Pandemi COVID-19. http://lipi.go.id/berita/ survei-kinerja-umkm-di-masa-pandemicovid19/22071. accessed on 22 July 2020.

Lembaga Ilmu Pengetahuan Indonesia. (2020, Mei 6). Implikasi Pembatasan Mobilitas selama Pandemi COVID-19 bagi Migran Muda. https://kependudukan.lipi.go.id/ id/berita/seputar-kegiatan-ppk/857implikasi-pembatasan-mobilitas-selamapandemi-covid-19-bagi-migran-muda. accessed on 11 September 2020.

Lembaga Ilmu Pengetahuan Indonesia. (2020, Juli 30). Pembatasan Mobilitas Penduduk dan Permasalahan Potensial Keamanan Kota di Masa Pandemi COVID-19. https://kependudukan.lipi. go.id/id/berita/53-mencatatcovid19/1022pembatasan-mobilitas-penduduk-danpermasalahan-potensial-keamanan-kotadi-masa-pandemi-covid-19. accessed on 11 September 2020.

Moleong, L. J. (2017). Metodologi Penelitian Kualitatif (Edisi Revisi). In PT. Remaja Rosda Karya.

Mufida, A. (2020). Polemik Pemberian Bantuan Sosial Di Tengah Pandemic Covid 19.ADALAH Buletin Hukum \& Keadilan, 4(1), pp. 159-166. doi: 10.15408/adalah.v4i1.15669.

Sotiropoulos, D. A., \& Bourikos, D. (2014). Economic Crisis, Social Solidarity and the Voluntary Sector in Greece. Journal of Power Politics \& Governance, 2 (2), pp. 33-53.
Sumarto, M. (2017). Welfare Regime Change in Developing Countries: Evidence from Indonesia. Social Policy and Administration, 51(6), pp.940-959. doi: 10.1111/spol.12340.

Sumner, A., Hoy, C., \& Ortiz-Juarez, E. (2020). Estimates of the impact of COVID-19 on global poverty (UNU-WIDER Working Paper 43/2020). doi: 10.35188/UNUWIDER/2020/800-9.

Suryahadi, A., Al Izzati, R., \& Suryadarma, D. (2020). The Impact of COVID-19 Outbreak on Poverty: An Estimation for Indonesia (SMERU Working Paper April 2020). Jakarta.

Syambudi, I. (2020). Kronologi Pembubaran Rapat Solidaritas Pangan Jogja Versi Polisi. Tirto.

https://tirto.id/kronologi-pembubaran-rapatsolidaritas-pangan-jogja-versi-polisi-ePXy accessed on 11 September 2020.

Wood, G. (2004). Informal security regimes: The strength of relationships. In Insecurity and Welfare Regimes in Asia, Africa and Latin America: Social Policy in Development Contexts. doi: 10.1017/ CB09780511720239.004.

World Health Organization. $(2020,10$ September). Rolling update on Coronavirus desase (COVID-19). https://www. who.int/emergencies/diseases/novelcoronavirus-2019. accessed on 11 September 2020.

World Health Organization. (2020,10 September). COVID-19: Physical Distancing. https:// www.who.int/westernpacific/emergencies/ covid-19/information/physical-distancing. accessed on 11 September 2020.

Yuda, T. K. (2017). Wajah Rezim Kesejahteraan. Republika (6 Juli 2017). 